\title{
Stages of uncertainty
}

\section{Stage Directions: Writing on Theatre 1970-2008 \\ by Michael Frayn \\ Faber and Faber: 2008. 288 pp. $€ 20$}

In Michael Frayn's 1998 play Copenhagen, physicists Niels Bohr and Werner Heisenberg, along with Bohr's wife Margrethe, reunite in the afterworld to work out the mystery of why Heisenberg visited Bohr in Copenhagen in 1941. The play has stimulated tremendous debate about the people and events it depicts. Frayn's new book includes his writings about the play both before it was staged and in response to this debate. It is useful to have them collected here alongside Frayn's other writings about theatre over the past three decades.

Stage Directions reveals much about the mind behind Copenhagen, a play he admits gave the 'kiss of life' to a playwriting career that was flagging in the 1990s. Just a few years earlier, in 1985, Frayn's career had been at its peak, with three of his works running in London simultaneously. One chapter, entitled 'On the Roller Coaster', charts the frenzied, out-of-control lurching between failure and success that characterized his early writing. A sense of precariousness has remained with him, even after unqualified stage successes like Copenhagen. Frayn isn't afraid to wallow in his failures. This, together with his readiness to place the contributions of the directors and actors he has worked with far above his own efforts, makes for appealing reading.

Frayn's theatre work spans everything from comedy and farce, opera and film, to serious drama and a substantial body of translations of Anton Chekhov's plays. He fondly recalls his childhood theatrical efforts, first at toy theatre and then at magic and conjuring tricks. Some hilarious mishaps, with the scenery crashing down around one particularly spectacular failure, planted the very productive seeds of his later farces such as Donkeys' Years and Noises Off.

To date, Copenhagen is Frayn's only venture into science on stage. Indeed, Copenhagen and Noises Off seem so remote from one another that it is hard to believe they are by the same playwright. Copenhagen plumbs some of the most difficult scientific and moral questions of our time; in a sense, it forms a trilogy with Frayn's two most recent plays, Democracy and Afterlife. Apart from the single-word titles, these all reflect Frayn's abiding Germanic interests and fascination with 'great men' on the stage of history - Heisenberg and other physicists in Copenhagen, German chancellor Willy Brandt

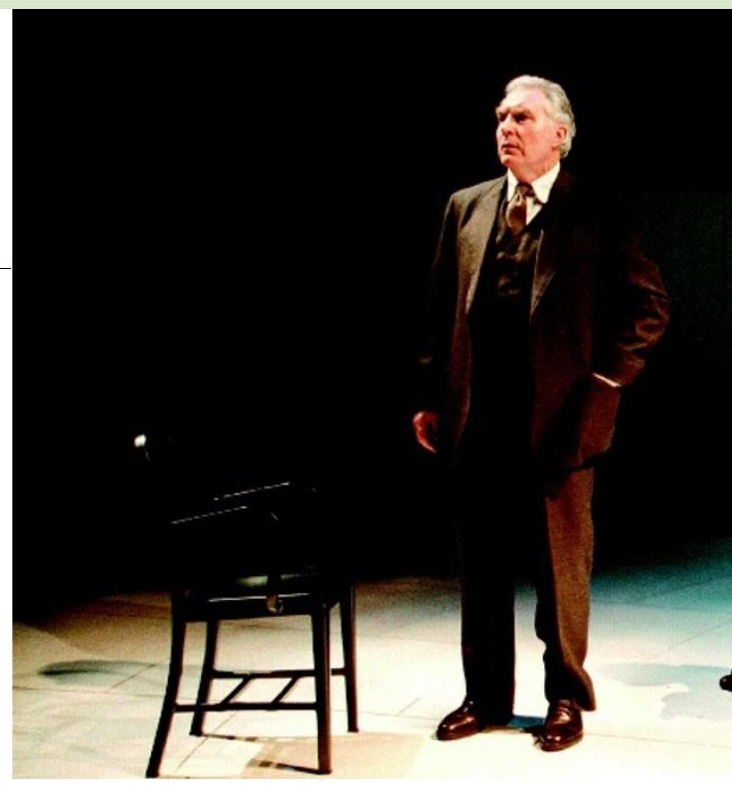

in Democracy and the Austrian (later American) theatre director Max Reinhardt in Afterlife. These men all met with failure and success. The plays probe the extent to which personal characteristics brought about these failures, and to what degree they were caused by political circumstances that overwhelmed the characters.

All three plays reflect Frayn's interest in 'the epistemology of intention', or the question of how we attempt - and fail - to know our own and others' thoughts and motives. The book reveals that this theme is already latent in his earliest plays. Another, more overt theme that he develops in his work is how we impose our ideas on the world around us.

Because Copenhagen, Democracy and Afterlife all involve real historical figures and situations,

\section{Saving plastics for posterity}

\section{Conservation of Plastics: Materials Science, Degradation and Preservation by Yvonne Shashoua Butterworth-Heinemann: 2008. 300 pp. $\$ 87.95, £ 49.99$}

Many modern cultural artefacts, from Neil Armstrong's space suit to works of art, contain plastics that may degrade readily. Museums now face the challenge of saving vulnerable and important examples for future generations. Yvonne Shashoua's book Conservation of Plastics is a timely, thoughtful and thorough review of the young discipline of plastics conservation. It will help conservators, curators, archivists and collectors of modern materials, and will be of interest to materials scientists and chemists.

Often misidentified by the untrained eye, plastics are present in scientific, technological and social historical collections, and increasingly in modern art and textiles. Certain twentiethcentury plastics, notably early polyvinyl chloride and polyurethane foams, degrade relatively swiftly and severely. Casualties include design icons such as the inflatable 1960s Blow Chair and highly collectable vintage Barbie dolls.

Semisynthetic plastics from the nineteenth century, especially cellulose nitrate (celluloid) and cellulose acetate, are particularly susceptible to degradation, whether the stimulus is physical, chemical or environmental. Irreversible damage to early celluloid cine film and its replacement, cellulose acetate safety film, pose a great problem for archivists. The earliest films and the historical evidence they contain may be lost unless they are transferred onto more robust media. The twentieth-century sculptor Naum Gabo used cellulose nitrate and cellulose acetate in his early works. Some have deteriorated so badly that conservators are turning to computer-aided methods to record their form.

Early steps to save plastics were discussed at a 1988 conference held by the Scottish Society for Conservation and Restoration. Several books followed. The 1993 Canadian Conservation Institute publication Saving the Twentieth Century, edited by David Grattan, established the discipline of plastics conservation. In their 1999 book Plastics: Collecting and Conserving, Anita Quye and Colin Williamson issued guidelines for the care of plastics in collections to acceptable museum and conservation standards.

A decade on, Shashoua's welcome and accessible book provides up-to-date, professional advice on caring for plastics, including associated risks and useful data. She provides context with introductory chapters on plastics in collections and the technology of plastics and their historical development, and uses her background as a polymer chemist and conservator to explain the nature of plastics, their types and related chemistry. Especially helpful are tables of frequently used additives, properties of plastics and the impact of chemical reactions in plastics, notably those caused by light, heat and oxygen.

To assist with the difficulty of identifying plastics, the book lists characteristic odours, recycling symbols and specific gravities. Shashoua discusses identification tests, including the controversial 'hot pin test', in which glowing hot pins are applied to the surface of a plastic object and note taken of the resulting marks and odours. This method is favoured by collectors and antique sellers, but rejected by museum professionals owing to the damage 


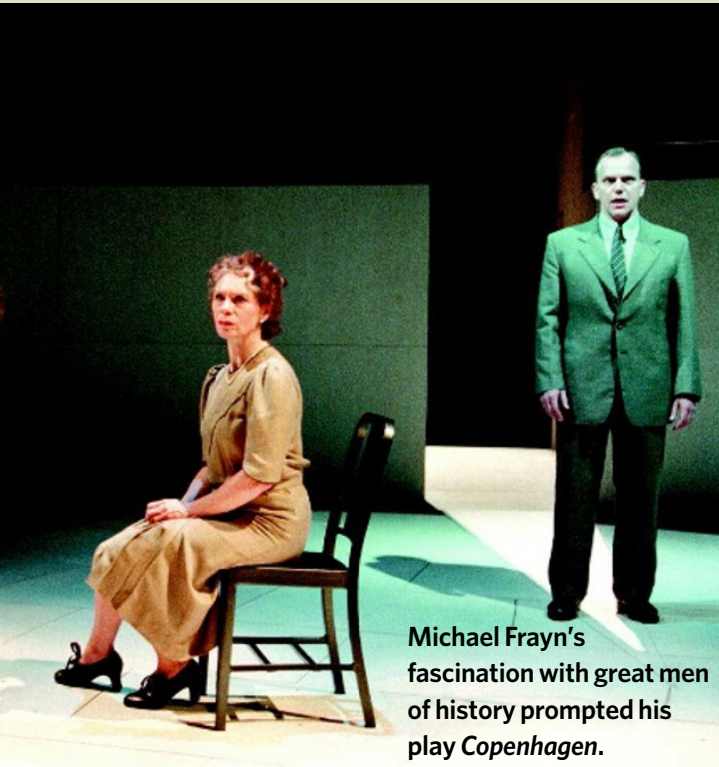

Frayn provides substantial 'postscripts' to each one, reprinted in the book, in which he lays out his source material, explains how he used it, and where and why he diverges from the historical record. For Copenhagen, he retraces the tremendous research he did into the physics and the physicists, from concepts of uncertainty and complementarity in quantum mechanics, to calculations of the critical mass of fissile material needed to make an atomic bomb, and the extent and nature of the German atomic weapons programme. His assessments of Bohr and Heisenberg are detailed and perceptive.

Frayn also discusses the 1945 detainment of Heisenberg and other German physicists at Farm Hall, a manor house outside Cambridge, UK, noting that 'the story of Farm Hall is another complete play in itself'. If only he would one day write it.

In a post-postscript, Frayn recounts how Copenhagen took on a life of its own and even changed the historical record, prompting first the revelation of draft letters from Bohr to Heisenberg about their 1941 meeting, and then the discovery of a letter Heisenberg wrote to his wife during that meeting, which took place, it turns out, on three separate days over a week. Although he wishes he had gained access to some of the documents earlier, especially Bohr's draft letters, he maintains that in the end, the play's integrity still stands.

One can see why he is drawn to Chekhov. The Russian, like Frayn, wrote novels and short stories before coming to playwriting late in life, for which he is arguably best known. Frayn's sympathy with Chekhov's 'struggles to understand and master the recalcitrant medium of the theatre' comes through in this fascinating collection: how difficult theatre is, by turns unpredictable, maddening, tedious, enthralling, crushing, exhilarating. In other words, just like science.

Kirsten E. Shepherd-Barr is a lecturer in modern drama at the University of Oxford, and a fellow and tutor in English at St Catherine's College, University of Oxford, UK. She is author of Science on Stage: From Doctor Faustus to Copenhagen.

e-mail: kirsten.shepherd-barr@ell.ox.ac.uk that can be incurred. She summarizes analytical techniques, including Fourier transform infrared and Raman spectroscopy, and supplies technical data that are useful to analytical chemists.

Shashoua includes dramatic case studies, such as the polyethylene head that was used to display a gas mask with vulcanized rubber strips. These had reacted chemically with the polyethylene so that the plastic head suffered irreversible and disfiguring degradation. This shows that sulphur-containing vulcanizing agents diffused from the gas mask into the polyethylene, and highlights the importance of using inert materials as display mounts for plastics.

Shashoua outlines available treatments, pitfalls associated with using solvents and the risks of cleaning and labelling plastics. She focuses on objects rather than media such as film, which is a specialization in itself. She highlights a need for better training for plastics curators, collectors and conservators, and outlines a strategy for surveying collections of plastics for degradation.

Global plastics production is rapidly increasing - around 230 million tonnes were produced in 2007. The compositions of emerging specialist plastics, such as composites, copolymers and blends, will make them even more difficult to identify and conserve and will challenge future collectors. With limited museum resources available, the future of plastics conservation will be subject to strict cost-benefit analysis. Saving Armstrong's space suit, for example, may warrant more expenditure than rescuing everyday, mass-produced plastic goods.

The book also touches on the conflicts between traditional conservation ethics and their application to new, short-lived materials, such as the biodegradable plastics being developed to offset mounting concerns about waste in landfills, landscapes and oceans. Biodegradable plastics provide increasing challenges to conservators as different types are being produced for an ever wider range of applications, from packaging to mobile phone casings.

The conservation of plastics is maturing as a discipline, but challenges lie ahead. Shashoua's guidelines in Conservation of Plastics do not supply all the answers, but they ensure the best chance of survival for current and future plastics collections into the twenty-second century. Susan Mossman is curator of Plasticity: 100 Years of Making Plastics at The Science Museum, London SW7 2DD, UK, and author of Fantastic Plastic.

\section{Robots refined}

The fifth ArtBots exhibition, running at Trinity College Dublin from 19-21 September, aims to challenge the traditional view of robots by showing that they can be art.

Just 15 of the 100 robots submitted have made this year's cut. Pete Redmond's RuBot II comes closest to what most expect a robot to be. With its humanoid torso, webcam eyes and pneumatic arms, the robot can solve a Rubik's cube in an average of 35 seconds.

Many of the works displayed subvert such stark efficiency. Allison Kudla's fragile-looking The Search For Luminosity frames six Oxalis plants with high-tech sensors and lights. When the plants raise their leaves looking for the expected Sun, a system of sensors turns on the exhibit's lights to provide sustenance. "The idea is about questioning and dismantling the hierarchy between the biological and the physical," says Kudla.

Other robots in the show look like they might date from before the Industrial Revolution. The most striking example is Ralf Baecker's Rechnender Raum ('Calculating Space'; pictured). "All the logic gates like and/or/not are formed by levers, strings and weights," explains Baecker. These units are connected by strings that communicate digital signals: a pulled string equals 1 , a loose string equals 0 . Through these strings, each cell in the framework receives and transmits instructions to neighbouring cells, resulting in a huge, primitive computer that sits and calculates with no regard to the viewer.

The show also features a panel discussion titled 'Are we living in a robotic cargo cult?'. Participants will discuss how ArtBot projects can confront the issue of whether current and future robots are "shaped by unrealistic and potentially de-humanizing science fiction fantasies". Their conclusions will feed in to an EU-funded project, Living with Robots and Interactive Companions.

Daniel Cressey is a reporter for Nature.

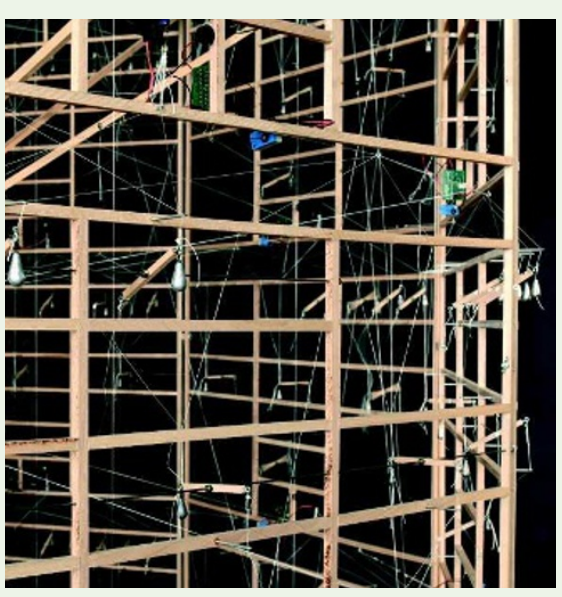

